\title{
Role of Sympathetic Nervous System in Immobilization- and Cold-induced Brown Adipose Tissue Thermogenesis in Rats
}

\author{
Hiroyuki Shibata and Tetsuo Nagasaka \\ Department of Physiology, School of Medicine, \\ Kanazawa University, Kanazawa, Ishikawa, 920 Japan
}

\begin{abstract}
The role of the sympathetic nervous system in 10-min cold $\left(5^{\circ} \mathrm{C}\right)$ - or 2-min immobilization-induced thermogenesis in brown adipose tissue (BAT) was studied in warm $\left(25^{\circ} \mathrm{C}\right)$-acclimated rats. Both coldand immobilization-stresses increased heat production $(M)$, interscapular brown adipose tissue temperature $\left(T_{\text {bat }}\right)$, and colonic temperature $\left(T_{\text {col }}\right)$. Resulting from both stresses, the increase in $T_{\text {bat }}$ was greater than that in $T_{\mathrm{col}}$, the differences $\left(\Delta T_{\mathrm{bat}}\right)$ becoming approximately 0.48 and $0.46^{\circ} \mathrm{C}$ by the cold exposure and the immobilization, respectively. After sympathectomy, $T_{\mathrm{bat}}$ and $\Delta T_{\mathrm{bat}}$ did not change on immobilization but increased significantly on the cold exposure. $\Delta T_{\mathrm{bat}}$ was $0.31^{\circ} \mathrm{C}$ in the sympathectomized rats at the end of the cold exposure period. Immobilization-induced BAT thermogenesis may be mainly controlled by the sympathetic nervous system. On the other hand coldinduced BAT thermogenesis seems to be controlled by certain hormonal factors as well as the sympathetic nervous system.
\end{abstract}

Key Words: sympathetic nervous system, immobilization, cold exposure, brown adipose tissue thermogenesis.

Brown adipose tissue (BAT) is a predominant site for nonshivering thermogenesis (NST) in rats (FoSTER and FRYDMAN, 1979). Heat production of BAT is controlled by norepinephrine (NE) released from the sympathetic nerve terminals in the tissue (Foster et al., 1980; SEYdoux and GirardiER, 1977). Moreover, several investigators have suggested that besides the sympathetic nervous system, BAT thermogenesis during cold exposure is controlled by hormones such as glucocorticoids (WüNNENBERG et al., 1974) and glucagon (KUROSHIMA et al., 1978). At a thermoneutral temperature, immobilization stress also induced BAT thermogenesis in rats (SHIBATA and NAGASAKA, 1982), and the importance of the sympathetic nerves to BAT thermogenesis during immobilization stress was

Received for publication April 15, 1983

柴田裕行, 永圾鉄夫 
confirmed. However, the role of factors other than the sympathetic nerves is not known in BAT thermogenesis elicited by immobilization stress. The purpose of the present study was to examine the contribution of certain hormonal factors in the increase in BAT thermogenesis induced by cold exposure and immobilization stress.

\section{METHODS}

Preparation. Male Wistar rats weighing 200-350 g were used. They were kept at $25 \pm 2^{\circ} \mathrm{C}$ and were provided with a commercial rat chow (Oriental MF, Oriental Yeast Co., Tokyo) and water ad libitum. Under pentobarbital anesthesia (Nembutal; $50 \mathrm{mg} / \mathrm{kg}$, i.p.), a Cu-Ct thermocouple $(0.3 \mathrm{~mm}$ o.d.) was fixed near the Sulzer's vein beneath the interscapular BAT (IBAT). In some rats, another thermocouple was fixed on back muscles near the thoraco-dorsal artery. These thermocouples were used for the measurement of the temperatures of IBAT and muscles. Twenty-four hours after the above operations, the animals were used for the following experiments.

Sympathectomy. Sympathectomy was achieved by a single injection (i.p.) of $100 \mathrm{mg} / \mathrm{kg}$ of 6-hydroxydopamine hydrobromide (6-OHDA: Aldrich Chemical Company, Inc.) $20 \mathrm{hr}$ prior to cold or immobilization stress. The 6-OHDA was prepared in $0.9 \%$ saline $(0.3 \mathrm{ml})$ containing $1 \mathrm{mg} / \mathrm{ml}$ of ascorbic acid.

Sympathectomy + adrenalectomy. One day after the sympathectomy, certain rats were subjected to bilateral adrenalectomy under pentobarbital anesthesia (Nembutal; $40 \mathrm{mg} / \mathrm{kg}$, i.p.). The animals were provided with rat chow and water containing $0.9 \%$ saline and $5 \%$ glucose. Cortisone acetate (Wako Chemical Co., Tokyo) was suspended in $0.9 \%$ saline $(0.5 \mathrm{ml})$ and was injected s.c. at a dose of $25 \mathrm{mg} /(\mathrm{kg} \cdot$ day) to provide glucocorticoids (MAICKel et al., 1967b). Twenty hours after the operation, the animals were reinjected with 6-OHDA $(100 \mathrm{mg} / \mathrm{kg}$, i.p.) and were used for the experiments $5-6 \mathrm{hr}$ after the injection.

Measurements. The animals were placed in a cylinder-type mesh wire cage of $7 \mathrm{~cm}$ diameter and $18 \mathrm{~cm}$ length closed at the frontal end in cone shape and having a wire-spring stopper at the rear end. They were allowed to move back and forth but not to turn around inside the cage. Colonic temperature $\left(T_{\mathrm{col} 1}\right)$ was measured with a thermistor probe inserted $7 \mathrm{~cm}$ beyond the anus and the probe wire was secured at the base of the tail with adhesive tape. $T_{\text {col } 1}, T_{\text {bat }}$, and back muscle temperature $\left(T_{\mathrm{m}}\right)$ were recorded continuously on potentiometers (SPH-6, Rikendenshi, Tokyo). The temperature difference between $T_{\mathrm{bat}}$ and $T_{\mathrm{col}}\left(\Delta T_{\mathrm{bat}}\right)$ was measured. Expired air was drawn (1.3 liters/min) through a hood covering the cage. The difference in $\mathrm{O}_{2}$ concentration between the expired air and the room-fresh air was measured by a Zirconia $\mathrm{O}_{2}$ analyzer (LC 700E, Toray, Osaka). Oxygen consumption $\left(\dot{V}_{\mathrm{O}_{2}}\right)$ was calculated from this difference and the rate of air flow. The rate of heat production $(M)$ was determined from $\dot{V}_{\mathrm{O}_{2}}$ assuming a 
respiratory quotient of 0.80 . Heat production was expressed in $\mathrm{W} / \mathrm{m}^{2}$. Body surface area $\left(\mathrm{m}^{2}\right)$ was estimated from the following equation: $\mathrm{m}^{2}=0.091 \times$ body weight $\left(\mathrm{kg}^{2 / 3}\right)$ (GUYTON, 1963).

Cold and immobilization stresses. After $2-3 \mathrm{hr}$ of resting at $27 \pm 2^{\circ} \mathrm{C}$, animals were subjected to an immobilization stress or a cold stress. Some of the animals were pushed at their hips with the wire-spring stopper for $2 \mathrm{~min}$, during which time they were not able to move. The rest of the animals were exposed to $5 \pm 2^{\circ} \mathrm{C}$ for $10 \mathrm{~min}$.

Measurement of NE content of IBAT. To confirm the effect of 6-OHDA on BAT, the content of NE was determined on pairs of IBAT from control and sympathectomized rats. The interscapular tissues were rapidly removed from rats exposed to 10 -min exposure of $5 \pm 2^{\circ} \mathrm{C}$ (not those used in temperature measurements) under pentobarbital anesthesia (Nembutal; $50 \mathrm{mg} / \mathrm{kg}$, i.p.). The tissues were placed in ice-cold $0.25 \mathrm{M}$ sucrose with $5 \mathrm{~mm}$ Tris $\left(\mathrm{pH} 7.4\right.$ at $23^{\circ} \mathrm{C}$ ). The removal of muscles, adhering white fat, and some connective tissues was done on a petri dish in crushed ice. The weighed pads were minced and homogenized in 5 volumes of $0.2 \mathrm{M} \mathrm{HClO}_{4}$. After removal of protein precipitate by centrifugation $(30,000 \times g$ for $30 \mathrm{~min})$, the extracts were run through alumina columns at pH 8.4-8.6 to absorb $\mathrm{NE}$ which then was eluated with $0.1 \mathrm{M} \mathrm{HCl}$ and determined by application of high performance liquid chromatography. A voltammetry detector (VMD-101, Yanaco, Kyoto) and a liquid chromatograph (L-2000, Yanaco, Kyoto) were used for the measurement.

Statistics. Values are presented as means \pm S.E. Data were subjected to an analysis of variance and a paired Student's $t$-test. Significance was set at $p<0.05$.

\section{RESULTS}

Effects of immobilization or cold exposure in the intact rats

Both stresses increased $M, T_{\mathrm{bat}}, T_{\mathrm{col}}$, and $\Delta T_{\mathrm{bat}}$. $T_{\mathrm{bat}}$ was higher than $T_{\mathrm{col}}$ after both stresses. $\Delta T_{\text {bat }}$ became 0.48 and $0.46^{\circ} \mathrm{C}$ on cold exposure and immobilization, respectively. The elevation of $M$ on cold exposure was greater than that of $M$ by immobilization (Fig. 1, Tables 1 and 2). $T_{\mathrm{m}}$ was always lower than $T_{\mathrm{col}}$. $\quad T_{\mathrm{m}}$ did not change on immobilization, but decreased on cold exposure $(p<$ $0.05)$.

\section{Effects of immobilization or cold exposure in the sympathectomized rats}

Immobilization did not change $T_{\text {bat }}$ and $T_{\text {col }}$ in the sympathectomized rats (Fig. 2, Table 2). There were no significant changes in $\Delta T_{\text {bat }}$. Cold exposure increased $M$ in the sympathectomized rats but to a lesser extent than that in the intact rats. $T_{\mathrm{col}}$ did not change during the cold exposure but decreased after exposure. $T_{\mathrm{bat}}(p<0.01)$ and $\Delta T_{\mathrm{bat}}(p<0.05)$ were increased by the exposure to 

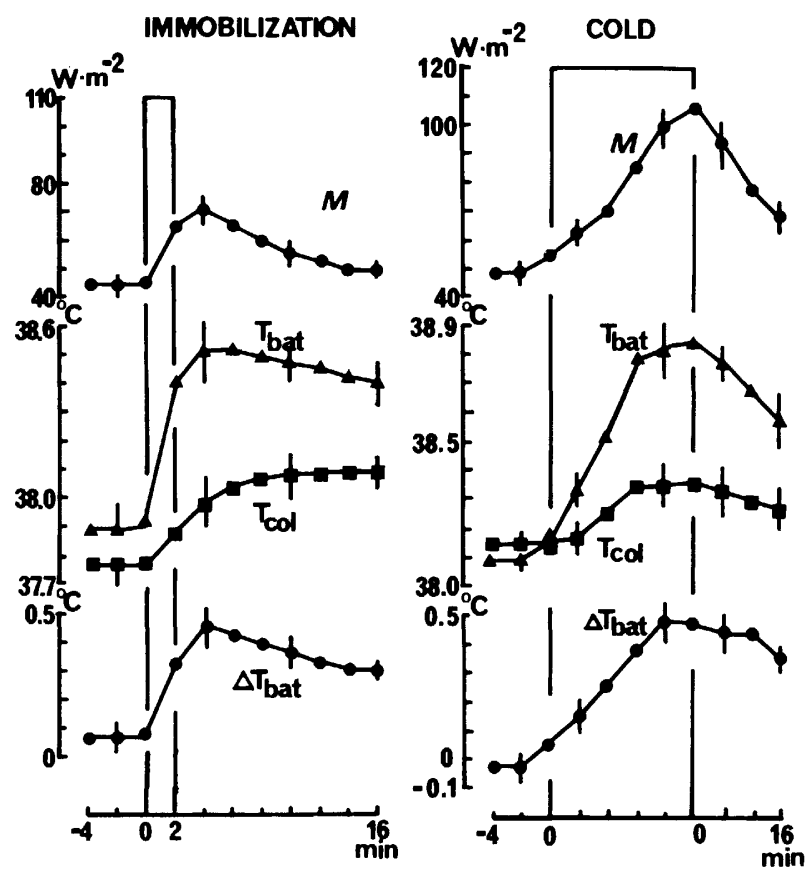

Fig. 1. Effects of immobilization $(n=7)$ and cold exposure $(n=7)$ on $M, T_{\mathrm{bat}}, T_{\text {col }}$, and $\Delta T_{\text {bat }}$ in intact rats. Columns indicate the duration of stress. Values are means. Vertical bars are \pm S.E.

Table 1. Changes in $M, T_{\mathrm{bat}}, T_{\mathrm{col}}$, and $\Delta T_{\mathrm{bat}}$ caused by cold exposure in intact and sympathectomized rats.

\begin{tabular}{cccc}
\hline & $\begin{array}{c}\text { Before cold } \\
\text { exposure }\end{array}$ & $\begin{array}{c}10 \text { min after } \\
\text { exposure }\end{array}$ & Changes \\
\hline Intact $(n=7)$ & & & \\
$M\left(\mathrm{~W} / \mathrm{m}^{2}\right)$ & $45.6 \pm 1.8$ & $108.0 \pm 4.0$ & $62.6 \pm 4.6^{*}$ \\
$T_{\text {col }}\left({ }^{\circ} \mathrm{C}\right)$ & $38.13 \pm 0.12$ & $38.36 \pm 0.09$ & $0.32 \pm 0.07^{*}$ \\
$T_{\text {bat }}\left({ }^{\circ} \mathrm{C}\right)$ & $38.07 \pm 0.15$ & $38.84 \pm 0.07$ & $0.77 \pm 0.16^{*}$ \\
$\Delta T_{\text {bat }}\left({ }^{\circ} \mathrm{C}\right)$ & $-0.06 \pm 0.05$ & $0.48 \pm 0.07$ & $0.57 \pm 0.09^{*}$ \\
Sympathectomized $(n=7)$ & & & \\
$M\left(\mathrm{~W} / \mathrm{m}^{2}\right)$ & $42.4 \pm 1.5$ & $87.4 \pm 2.7$ & $45.5 \pm 2.1^{*}$ \\
$T_{\text {col }}\left({ }^{\circ} \mathrm{C}\right)$ & $37.51 \pm 0.23$ & $37.53 \pm 0.25$ & $-0.04 \pm 0.07$ \\
$T_{\text {bat }}\left({ }^{\circ} \mathrm{C}\right)$ & $37.60 \pm 0.24$ & $37.88 \pm 0.27$ & $0.19 \pm 0.09$ \\
$J T_{\text {bat }}\left({ }^{\circ} \mathrm{C}\right)$ & $0.06 \pm 0.03$ & $0.31 \pm 0.05$ & $0.21 \pm 0.05^{*}$ \\
\hline
\end{tabular}

Data presented as mean \pm S.E. $\quad *$ Significant changes from resting values $(p<0.01)$.

cold. The rise in $\Delta T_{\text {bat }}$ was $0.57^{\circ} \mathrm{C}$ in the intact rats and $0.21^{\circ} \mathrm{C}$ in the sympathectomized rats (Table 1$)$. 


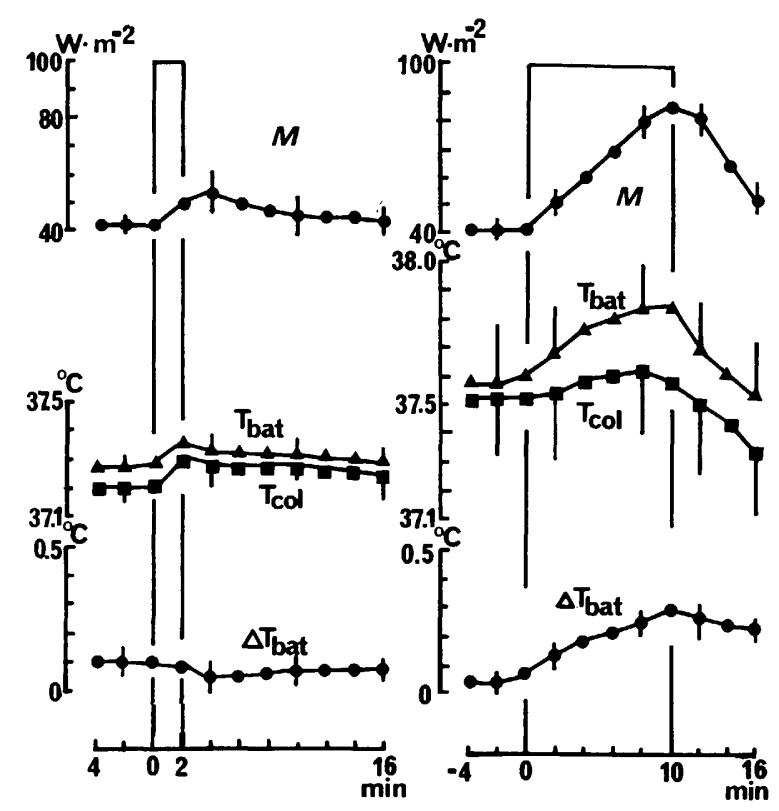

Fig. 2. Effects of immobilization $(n=6)$ and cold exposure $(n=7)$ on $M, T_{\text {bat }}, T_{\text {col }}$, and $\Delta T_{\text {bat }}$ in the sympathectomized rats. Columns indicate the duration of stress. Values are means. Vertical bars are \pm S.E. Cold exposure increased $T_{\text {bat }}(p<0.01)$ and $\Delta T_{\text {bat }}(p<0.05)$ in the sympathectomized rats.

Table 2. Changes in $M, T_{\text {bat }}, T_{\text {col }}$, and $\Delta T_{\text {bat }}$ caused by immobilization in intact and sympathectomized rats.

\begin{tabular}{cccc}
\hline & $\begin{array}{c}\text { Before } \\
\text { immobilization }\end{array}$ & $\begin{array}{c}2 \text { min after } \\
\text { immobilization }\end{array}$ & Changes \\
\hline Intact $(n=7)$ & & & \\
$M\left(\mathrm{~W} / \mathrm{m}^{2}\right)$ & $45.2 \pm 1.1$ & $74.2 \pm 3.1$ & $29.0 \pm 2.8^{*}$ \\
$T_{\text {col }}\left({ }^{\circ} \mathrm{C}\right)$ & $37.66 \pm 0.07$ & $37.87 \pm 0.06$ & $0.21 \pm 0.02^{*}$ \\
$T_{\text {bat }}\left({ }^{\circ} \mathrm{C}\right)$ & $37.82 \pm 0.11$ & $38.46 \pm 0.14$ & $0.64 \pm 0.09^{*}$ \\
$\Delta T_{\text {bat }}\left({ }^{\circ} \mathrm{C}\right)$ & $0.07 \pm 0.05$ & $0.46 \pm 0.07$ & $0.38 \pm 0.05^{*}$ \\
Sympathectomized $(n=6)$ & & & \\
$M\left(\mathrm{~W} / \mathrm{m}^{2}\right)$ & $41.7 \pm 1.3$ & $59.0 \pm 1.7$ & $13.3 \pm 1.2^{*}$ \\
$T_{\text {cal }}\left({ }^{\circ} \mathrm{C}\right)$ & $37.14 \pm 0.12$ & $37.21 \pm 0.10$ & $0.05 \pm 0.03$ \\
$T_{\text {bat }}\left({ }^{\circ} \mathrm{C}\right)$ & $37.24 \pm 0.16$ & $37.23 \pm 0.12$ & $-0.01 \pm 0.04$ \\
$\Delta T_{\text {bat }}\left({ }^{\circ} \mathrm{C}\right)$ & $0.11 \pm 0.07$ & $0.03 \pm 0.06$ & $-0.08 \pm 0.04$ \\
\hline
\end{tabular}

Data presented as mean \pm S.E. $\quad *$ Significant changes from resting values $(p<0.01)$

\section{Effects of cold exposure on sympathectomized, adrenalectomized rats}

The cold exposure did not change $T_{\text {bat }}$ for $8 \mathrm{~min}$, but decreased $T_{\mathrm{col}}$ and $T_{\mathrm{m}}$. The difference between $T_{\text {bat }}$ and $T_{\mathrm{m}}$ was increased $(p<0.05) . \quad \Delta T_{\text {bat }}$ was also increased by the cold exposure $(p<0.01)$.

Vol. 34, No. 1, 1984 


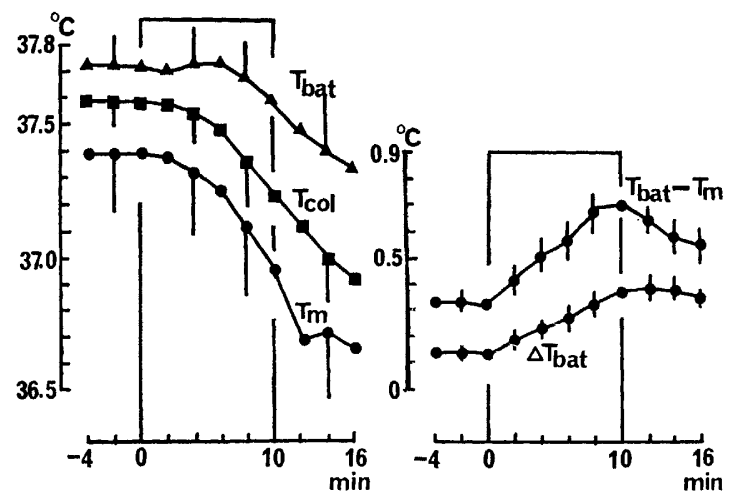

Fig. 3. Effects of cold exposure on $T_{\mathrm{bat}}, T_{\mathrm{col}}$, and $T_{\mathrm{m}}$ in sympathectomized, adrenalectomized rats $(n=4) . \quad \Delta T_{\mathrm{bat}}(p<0.01)$ and $\left(T_{\mathrm{bat}}-T_{\mathrm{m}}\right) \quad(p<0.05)$ were increased by the exposure. Columns indicate the duration of stress. Values are means. Vertical bars are \pm S.E.

Table 3. Effect of 6-OHDA on the content of NE in IBAT.

\begin{tabular}{lcc}
\hline & Control $(n=9)$ & 6-OHDA treated $(n=6)$ \\
\hline Fresh weight $(\mathrm{g})$ & $0.20 \pm 0.03$ & $0.24 \pm 0.03$ \\
Content of NE $(\mathrm{nmol} / \mathrm{g})$ & $3.81 \pm 0.24$ & $0.25 \pm 0.06$ \\
\hline
\end{tabular}

Data presented as mean \pm S.E.

Effects of 6-OHDA on the content of NE in IBAT

The content of NE in IBAT decreased to $7 \%$ of the control values after the injection of 6-OHDA (Table 3), which indicated an almost complete sympathectomy of IBAT.

\section{DISCUSSION}

In this study, the rate of heat production of BAT was estimated from the changes in $T_{\text {bat }}$ and $\Delta T_{\text {bat }}$. A $T_{\text {bat }}$ higher than $T_{\text {col }}$ is thought to reflect the rate of heat production of IBAT (SMITH and HORWITZ, 1969; BRÜCK and WÜNNENBERG, 1965; HeIM and Hull, 1966). We thought that the thermogenesis of IBAT was increased when both $T_{\text {bat }}$ and $\Delta T_{\text {bat }}$ were increased.

The 10-min cold exposure significantly increased $T_{\text {bat }}$ and $\Delta T_{\text {bat }}$ (Fig. 1). BAT thermogenesis during cold exposure was reduced, but not abolished, by the sympathectomy (Fig. 2, Table 1). It has been suggested that besides the sympathetic nervous system, other factors are involved in the control of BAT thermogenesis. NE released from the sympathetic nerves activates BAT through its $\beta$-effect (BUKOWIECKI et al., 1980), but $\beta$-antagonists cannot abolish completely nonshivering thermogenesis induced by cold exposure in new-born rabbits (HeIM 
and Hull, 1966) and hedgehogs (WÜNNENBERG et al., 1974). Furthermore, an increase in blood flow to BAT or cold exposure was not suppressed by a ganglionic blocker, hexamethonium (Kuroshima et al., 1967). ACTH (HeIM and Hull, 1966) and glucagon (KUROSHIMA et al., 1978) cause BAT thermogenesis. In addition, hormones secreted from the adrenal glands, glucocorticoids (WüNNENBERG et al., 1974) and epinephrine (COTTLE and CARLSON, 1956) were suggested to promote nonshivering thermogenesis.

As shown in Fig. 3, the 10-min cold exposure decreased $T_{\mathrm{col}}$ and $T_{\mathrm{m}}$ in the sympathectomized and adrenalectomized rats. $T_{\mathrm{bat}}$ did not change for $8 \mathrm{~min}$ after the onset of cold exposure, and decreased slightly afterwards. The difference between $T_{\mathrm{bat}}$ and $T_{\mathrm{m}}$ was significantly increased during the 10-min cold exposure. Factors other than adrenal hormones seem to be involved in cold-induced BAT thermogenesis in sympathectomized rats. $\mathrm{ACTH}$ and/or glucagon might be responsible for BAT thermogenesis elicited by cold exposure in both sympathectomized and adrenalectomized rats.

The 2-min immobilization increased BAT temperature to the same extent as that on 10-min exposure to cold (Fig. 1). However, the BAT thermogenesis was abolished by sympathectomy (Fig. 2, Table 2), which indicated that BAT thermogenesis caused by immobilization was mainly controlled by the sympathetic nervous system. This conclusion seems to be supported by our previous work, in that sections of the sympathetic nerves supplying BAT abolished BAT thermogenesis caused by immobilization (ShIBATA and NAGASAKA, 1982). These results indicate that the mechanism of BAT thermogenesis after immobilization may be different from that following cold exposure.

Sympathectomy suppressed elevations of $M$ caused by cold exposure (Fig. 2, Table 1). Shivering is not normally considered to be a function of the sympathetic nervous system (Hemingway and Price, 1968). In addition, the rises in $T_{\text {bat }}$ and $\Delta T_{\text {bat }}$ were suppressed by sympathectomy (Fig. 2, Table 1). Therefore, the suppression of $M$ was thought to be due to that of nonshivering thermogenesis. However, chemical sympathectomy impaired shivering, and it is suggested that the sympathetic nervous system plays some role in the maintenance of shivering (GILGEN et al., 1962; MAICKEL et al., 1967a). Impaired shivering might be attributable to the suppression of $M$ and $T_{\mathrm{col}}$ in the sympathectomized rats, although we did not examine the intensity of shivering by using an electromyogram.

$T_{\text {col }}$ was decreased by cold exposure in the sympathectomized (Fig. 2), and in sympathectomized, adrenalectomized rats (Figs. 2 and 3). Vasoconstriction and piloerection in response to cold were suppressed by sympathectomy and this suppression was enhanced after the removal of adrenal medulla (MAICKEL et al., 1967a). The falls in $T_{\text {col }}$ must have been partly due to the increased heat loss of the animals.

Although it has been often reported that immobilization causes hypothermia in rats (BARTLETT et al., 1958; HérouX and HART, 1954), immobilization caused 
hyperthermia in this experiment. These contradictory results seem to be due to the differences in the ambient temperatures wherein immobilization was carried out. Immobilization increases heat loss as well as heat production (NAGASAKA et al., 1979) and the increase in heat loss becomes greater than that in heat production as the ambient temperature decreases (SHIBATA and NAGASAKA, 1983). Below the thermoneutral temperature, immobilization seems to cause negative thermal balance, resulting in hypothermia. AlKA and SANYAL (1978) showed that immobilization caused ambient temperature-dependent changes in rectal temperature, i.e., hyperthermia in warm temperatures and hypothermia at cold temperatures.

In our previous paper (NAGASAKA et al., 1980), we reported reduction of cardiac output and blood flow to BAT caused by 30-min immobilization in rats, and concluded that BAT thermogenesis may not be enhanced by forced immobilization. The prolonged compression of the thorax may have disturbed venous return to the heart and BAT thermogenesis. In this study, rats were immobilized for only $2 \mathrm{~min}$ in order to avoid compression of the thorax, and the rats showed enhanced BAT thermogenesis during and after the immobilization.

We thank Dr. H. Matsui for his kind help in the determination of norepinephrine of brown adipose tissue. This work was supported in part by a Grant-in-Aid for Scientific Research from the Ministry of Education, Science and Culture of Japan (Nos. 00548106 and 58480119).

\section{REFERENCES}

AlKA, A. and SAnYal, A. K. (1978) Immobilization stress in rats: Effect on rectal temperature and possible role of brain monoamines in hypothermia. Psychopharmacology, 73: 157160.

Bartlett, R. G., Mante, N., Jr., Foster, G. L., and Bernstein, P. (1958) Core to surface thermal gradients in the rat at several environmental temperatures. Am. J. Physiol., 193: 541-546.

BRÜCK, K. and WÜNNENBERG, B. (1965) Untersuchungen über die Bedeutung des multiloculären Fettgewebes für die Thermogenese des neugeborenen Meerschweichens. Pflügers Arch., 283: $1-6$.

Bukowiecki, L., Follé, N., Paradis, A., and Collet, A. (1980) Stereospecific stimulation of brown adipocyte respiration by catecholamines via $\beta$-adrenoreceptors. Am. J. Physiol., 238: E552-E556.

CotTle, W. H. and CARLSON, L. D. (1956) Regulation of heat production in cold-adapted rats. Proc. Soc. Exp. Biol. Med., 92: 845-849.

Foster, D. O., Depocas, F., and Frydman, M. L. (1980) Noradrenaline-induced calorigenesis in warm- and in cold-acclimated rats: Relations between concentration of noradrenaline in plasma, blood flow to differently located masses of brown adipose tissue, and calorigenic response. Can. J. Physiol. Pharmacol., 58: 915-924.

Foster, D. O. and Frydman, M. L. (1979) Tissue distribution of cold-induced thermogenesis in conscious warm- or cold-acclimated rats reevaluated from changes in tissue blood flow: The dominant role of brown adipose tissue in the replacement of shivering by nonshivering thermogenesis. Can. J. Physiol. Pharmacol., 57: 257-270. 
Gilgen, A., Maickel, R. P., Nicodijevic, O., and Brodie, B. B. (1962) Essential role of catecholamines in the mobilization of free fatty acids and glucose after exposure to cold. Life Sci., 1: 709-715.

GuYton, A. C. (1963) Circulatory Physiology: Cardiac Output and Its Regulation, Saunders, Philadelphia, pp. 11-12.

HeIm, T. and Hull, D. (1966) The effect of propranolol on the calorigenic response in brown adipose tissue of new-born rabbits to catecholamines, glucagon, corticotrophin and cold exposure. J. Physiol. (Lond.), 187: 271-283.

Hemingway, A. and Price, W. M. (1968) The autonomic nervous system and regulation of body temperature. Anesthesiology, 29: 693-701.

HÉroux, O. and HART, J. S. (1954) Restraint hypothermia and its inhibition by cold acclimation. Am. J. Physiol., 177: 219-221.

Kuroshima, A., DoI, K., and Ohno, T. (1978) Role of glucagon in metabolic acclimation to cold and heat. Life Sci., 23: 1405-1410.

Kuroshima, A., Konno, N., and IтHo, S. (1967) Increase in the blood flow through brown adipose tissue in response to cold exposure and norepinephrine in the rat. Jpn.J. Physiol., 17: 523-537.

Maickel, R. P., Matussek, N., Stern, D. N., and Brodie, B. B. (1967a) The sympathetic nervous system as a homeostatic mechanism. I. Absolute need for sympathetic nervous function in body temperature maintenance of cold exposed rats. J. Pharmacol. Exp. Ther., 157: 103-110.

Maickel, R. P., Stern, D. N., Takabatake, E., and Brodie, B. B. (1967b) The sympathetic nervous system as homeostatic mechanism. II. Effect of adrenocortical hormones on body temperature maintenance of cold-exposed adrenalectomized rats. J. Pharmacol. Exp. Ther., 157: 111-116.

Nagasaka, T., Hirata, K., Shibata, H., and Sugano, Y. (1980) Metabolic and cardiovascular changes during physical restraint in rats. Jpn. J. Physiol., 30: 799-803.

NagasaKa, T., Hirata, K., Sugano, Y., and Shibata, H. (1979) Heat balance during physical restraint in rats. Jpn. J. Physiol., 29: 383-392.

Seydoux, J. and Girardier, L. (1977) Control of brown fat thermogenesis by the sympathetic nervous system. Experientia, 33: 1128-1230.

Shibata, H. and Nagasaka, T. (1982) Contribution of nonshivering thermogenesis to stressinduced hyperthermia in rats. Jpn. J. Physiol., 32: 991-995.

Shibata, H. and NAGASAKA, T. (1983) Thermal balance of immobilized rats at various ambient temperatures. J. J. Aerospace Environ. Med., 20, 66-71.

Smith, R. E. and Horwitz, B. A. (1969) Brown fat and thermogenesis. Physiol. Rev., 49: $330-425$.

WüNnenberG, W., Merker, G., and BrüCK, K. (1974) Do corticosteroids control heat production in hibernators? Pflügers Arch., 352: 11-16.

Vol. 34, No. 1, 1984 